\title{
TRANSPARANSI ANGGARAN: SUATU UPAYA EFISIENSI DAN ANTISIPASI KORUPSI DI INDONESIA
}

\author{
Oleh: Rahmani Timorita Yulianti ${ }^{1}$
}

\begin{abstract}
Budget transparency is believed to be able to develop an effective, efficient, and corruptionfree organization system. Implementing it will enable an organization to erase any unnecessary budget. A more transparent budget also implies stakeholders' consultation in every step of budgeting to eliminate all sources of manipulation and corruption. In Indonesia marking up budget by posting some irrelevant and fictive activities is still commonly happening. It has been part of commonly used way to corrupt. Based on these situations, this paper will discuss how budget functions and principles, Islamic base value for budgeting, and how controlling system on budget should be implemented in order to efficiently anticipate corruption.
\end{abstract}

Keywords: transparansi, anggaran, efisiensi, korupsi

\section{Pendahuluan}

Secara teoritis, melalui transparansi anggaran dapat diperoleh suatu sistem organisasi yang lebih efisien, efektif dan bebas korupsi. Tidak tanggung-tanggung, transparansi anggaran dilakukan dengan menghapuskan seluruh mata anggaran yang belum jelas kegunaannya, misalnya dalam kategori “non-budgeter”. Dengan sistem anggaran yang lebih transparan tersebut, semua perencanaan anggaran harus dikonsultasikan kepada para stake-holdernya. Sehingga tidak ada lagi peluang untuk korupsi dan kong-kalikong lainnya.

Tetapi realitas di Indonesia, masih terjadi mark-up budget ${ }^{2}$ yaitu menaikkan nilai anggaran dari nilai yang sebenarnya, yang termasuk dalam salah satu modus korupsi. Biasanya hal tersebut terjadi dalam proyek dengan cara menggelembungkan besarnya dana proyek dengan cara memasukkan pos-pos pembelian yang sifatnya fiktif (split budget). ${ }^{3}$ Misalnya dalam anggaran dimasukkan pembelian komputer tetapi

${ }^{1}$ Dosen Program Studi Ekonomi Islam FIAI UII dan MSI UII, peserta Program Doktor Ekonomi Islam UIN Sunan Kalijaga Yogyakarta, email: rahmani_ty@yahoo.com

${ }^{2}$ Indonesia Corruption Watch, Korupsi Anggaran, Materi Training Jogjakarta, 29 Agustus - 1 September 2006

${ }^{3}$ Modus korupsi anggaran yang lain seperti anggaran bertumpuk (double budgeting), misalnya dalam suatu anggaran terdapat alokasi dana tunjangan kesejahteraan sebesar Rp 2 juta/orang per bulan. Tapi di pos lain, muncul bentuk lain tunjangan pemeliharaan kesehatan sebesar Rp 367.014.000,-. Padahal, kedua item itu sebenarnya adalah sama-sama sebagai asuransi kesehatan dalam bentuk jaminan. Sehingga telah terjadi duplikasi atau pengulangan item anggaran untuk satu hal. 
Rahmani Timorita Yulianti: Transparansi Anggaran : Suatu Upaya...

pada praktiknya tidak ada komputer yang dibeli atau kalau komputer dibeli harganya lebih murah. ${ }^{4}$ Dalam hal ini modus yang digunakan adalah dengan membuat item atau mata anggaran yang sebenarnya tidak pernah direalisasikan untuk tujuan itu, namun dialokasikan untuk kepentingan lainnya.

Dalam ilustrasi di atas, terdapat kemungkinan ada kebocoran anggaran sehingga tidak semua dana dialokasikan untuk proyek tersebut. Sudah menjadi rahasia umum, kontraktor harus menyisihkan dana sekian persen untuk oknum-oknum di birokrasi agar dimenangkan dalam tender dan mendapatkan proyek. Dalam berbagai kasus selama Orde Baru, proses penentuan kebijakan termasuk dalam penganggaran hanya formalitas belaka, sebab di balik prosedur formal tersebut sebenarnya sudah tersisipkan titipan-titipan dari para kolega dan kroni-kroni yang memanfaatkan kedekatannya dengan penguasa, untuk memperkaya diri, keluarga, dan atau kelompoknya. ${ }^{5}$

Rencana kegiatan atau program pembangunan yang dibuat hanya untuk memenuhi kebutuhan kelompok jaringan. Proyek ditetapkan berdasarkan pesanan sponsor dengan mengatasnamakan kebutuhan rakyat. Padahal rakyat sama sekali tidak pernah dilibatkan dalam setiap perancangan program pembangunan. Rakyat dalam pengertian di sini adalah kelompok non elit yang tidak memiliki akses di pemerintahan dan kekuasaan serta merupakan kelompok masyarakat yang terbesar atau mayoritas sosial. Kesulitan memberantas praktik korupsi anggaran diduga disebabkan oleh realitas bahwa praktik tersebut telah terlanjur membudaya (atau setidak-tidaknya melembaga) dalam wujudnya yang riil dan justru terbukti secara de facto fungsional.

Kejatuhan rezim Orde Baru telah menerbitkan harapan publik bahwa tindak kejahatan korupsi tersebut akan mampu diberantas secara berarti. Ketersediaan dan pembaruan dalam kebijakan publik, hukum, institusi dan organisasi anti korupsi telah nyaris lengkap dan memadai bagi upaya pemberantasan korupsi. Namun demikian, kesemua itu belum mampu menurunkan tingkat korupsi secara signifikan. ${ }^{6}$

\footnotetext{
${ }^{4}$ Admin, "Modus Korupsi”, dikutip dari http://www.transparansi.or.id/ ?pilih=lihataboutcorruption\&id=7

${ }^{5}$ Iskandar Siregar, “Menuju Era Transparansi Anggaran”, dikutip dari http:// www.kabarindonesia.com/berita.php?pil=20\&jd=Menuju+Era + Transparansi + Anggaran $\& d n=20080627090126$. accessed 11 Agu 2009 15:44:38 GMT

${ }^{6}$ Indeks Persepsi Korupsi (IPK) Indonesia Tahun 2004 diberi nilai 2,0 (termasuk tertinggi di dunia). Berdasarkan survei yang dilakukan The Political and Economic Risk Consultancy Ltd (PERC) bulan Januari hingga Februari 2005 terhadap 900 ekspatriat di Asia sebagai responden , Indonesia menduduki peringkat pertama sebagai negara terkorup se-Asia. Selanjutnya lihat M.Syamsa Ardisasmita (Deputi Bidang Informasi dan Data Komisi Pemberantasan Korupsi), Peran Transparansi Anggaran Dalam Pemberantasan Korupsi, Training dilaksanakan oleh Forum Indonesia Untuk Transparansi Anggaran, 12 Maret 2005.
} 
Dalam proses gerakan reformasi bergulir, gerakan pemberantasan korupsi berjalan lamban. Tidak berlebihan jika pemberantasan korupsi merupakan agenda reformasi yang paling kedodoran, bahkan menjadi lebih merajalela seiring bergulirnya proses reformasi. Praktik dan tindak korupsi menjangkiti semua sektor (publik, privat, dan civil society), serta semua level pemerintahan baik lokal hingga pusat. ${ }^{7}$

Seiring dengan perkembangan wacana dan praktik ekonomi Islam di Indonesia, bagaimana merespon fenomena inefisiensi dan korupsi anggaran tersebut? Bagaimana sebenarnya fungsi dan prinsip anggaran? Bagaimana integrasi nilai-nilai dasar Islam dalam anggaran? Dan bagaimana sistem pengawasan anggaran sebagai upaya efisiensi dan antisipasi korupsi di Indonesia?

\section{Fungsi dan Prinsip Anggaran}

Anggaran (budget) merupakan suatu alat perencanaan mengenai pengeluaran dan pendapatan pada masa yang akan datang, umumnya disusun secara sistematis yang meliputi seluruh kegiatan, yang dinyatakan dalam unit (kesatuan) moneter dan berlaku untuk jangka waktu (periode) tertentu di masa yang akan datang. Anggaran juga berfungsi sebagai alat kontrol atau pengawasan, baik terhadap pendapatan maupun pengeluaran pada masa yang akan datang. ${ }^{8}$ Dalam hal ini Glenn A Welsch mendefinisikan anggaran sebagai "Profitplanning and control may be broadly as defined as sistematic and formalized approach for accomplishing theplanning, coordinating and control responsibility of management ${ }^{\text {"9 }}$

Dari pengertian di atas, anggaran dikaitkan dengan fungsi-fungsi dasarmanajemen yang meliputi fungsi perencanaan, koordinasi dan pengawasan. Dengan demikian, bila anggaran dihubungkan dengan fungsi dasar manajemen maka anggaran meliputi fungsi perencanaan, mengarahkan, mengorganisasi dan mengawasi setiap satuan dan bidang-bidang organisasional di dalam badan usaha.

Dari definisi di atas, dapat diambil beberapa kesimpulan :

1. Anggaran harus bersifat formal artinya, anggaran disusun dengan sengaja dan bersungguh-sungguh dalam bentuk tertulis dan teliti.

2. Anggaran harus bersifat sistematis artinya, anggaran disusun dengan berurutan dan berdasarkan logika.

3. Setiap manajer dihadapkan pada suatu tanggungjawab untuk mengambil keputusan, sehingga anggaran merupakan hasil pengambilan keputusan yang berdasarkan asumsi tertentu.

\footnotetext{
${ }^{7}$ Kompas, 25 Mei 2003.

${ }^{8}$ Ida Bagus Putu Purbadharmaja, "Kajian Terhadap Fungsi Anggaran Dalam Pembangunan Ekonomi Daerah", Buletin Studi Ekonomi, Volume 12 Nomor 3 Tahun 2007, hal. 272, kolom 1.

${ }^{9}$ Glenn A.Welsch, Budgeting Profit Planning and Control, fourth edition, (New Delhi: prentice hall of India Private Limited, 1981), hal.3
} 
Rahmani Timorita Yulianti: Transparansi Anggaran : Suatu Upaya...

4. Untuk keputusan yang diambil oleh manajer tersebut, merupakan pelaksanaan fungsi manajer dari segi perencanaan, pengorganisasian, mengarahkan dan pengawasan.

Tugas penyusunan anggaran tersebut merupakan tanggung jawab dari pimpinan tertinggi perusahaan. Namun demikian tugas penyusunan anggaran selanjutnya dapat didelegasikan kepada bagian yang terkait pada perusahaan (tergantung struktur perusahaan). Adapun beberapa bagian yang dapat memperoleh pendelagasian penyusunan budget adalah:

a. Bagian administrasi (bagi perusahaan kecil), karena seluruh data aktivitas perusahaan baik produksi, pemasaran maupun yang lainnya terkumpul pada bagian ini.

b. Panitia atau tim anggaran (bagi perusahaan besar), terdiri dari pimpinan dan wakil masing-masing bagian terkait. ${ }^{10}$

Anggaran yang telah selesai disusun baik oleh bagian administrasi maupun panitia anggaran (tergantung organisasi perusahaan), disebut sebagai draft budget (rancangan budget), sedangkan apabila rancangan tersebut telah diserahkan, disetujui dan disahkan oleh pimpinan tertinggi perusahaan disebut sebagai budget yang definitif. ${ }^{11}$

Sedangkan peranan anggaran pada suatu perusahaan merupakan alat untuk membantu manajemen dalam pelaksanaan fungsi perencanaan, koordinasi, pengawasan dan juga sebagai pedoman kerja dalam menjalankan perusahaan untuk tujuan yang telah ditetapkan. Fungsi-fungsi tersebut adalah:

\section{Fungi Perencanaan}

Perencanaan merupakan salah satu fungsi manajemen dan fungsi ini merupakan dasar pelaksanaan fungsi-fungsi manajemen lainnya. Winardi memberikan pengertian mengenai perencanaan sebagai berikut:

"Perencanaan meliputi tindakan memilih dan menghubungkan fakta-fakta dan membuat serta menggunakan asumsi-asumsi mengenai masa yang akan datang dalam hal memvisualisasi serta merumuskan aktifitas-aktifitas yang diusulkan yang dianggap perlu untuk mencapai basil yang diinginkan". ${ }^{12}$

Dari kutipan di atas disimpulkan bahwa sebelum perusahaan melakukan operasinya, pimpinan dari perusahaan tersebut harus lebih dahulu merumuskan kegiatan-kegiatan apa yang akan dilaksanakan di masa datang dan hasil yang akandicapai

${ }^{10}$ Masodah, "Penganggaran Perusahaan (Budgeting)”, dikutip dari http://www.google.co.id/ search?hl=id\&cr=countryID\&q=related:masodah.staff.gunadarma.ac.id/Downloads/files/6633/ Pp3.doc

${ }^{11}$ Ibid.

${ }^{12}$ Winardi, Azas-azas Manajemen, edisi ketujuh, (Bandung: Penerbit Alumni,1983), hal.149 
dari kegiatan-kegiatan tersebut, serta bagaimana melaksanakannya. Dengan adanya rencana tersebut, maka aktifitas akan dapat terlaksana dengan baik.

\section{Fungsi Pengawasan}

Anggaran merupakan salah satu cara mengadakan pengawasan dalam perusahaan. Pengawasan itu merupakan usaha-usaha yang ditempuh agar rencanayang telah disusun sebelurnnya dapat dicapai. Dengan demikian pengawasan adalah mengevaluasi prestasi kerja dan tindakan perbaikan apabila perlu. ${ }^{13}$

Aspek pengawasan yaitu dengan membandingkan antara prestasi dengan yang dianggarkan, apakah dapat ditemukan efisiensi atau apakah para manajer pelaksana telah bekerja dengan baik dalam mengelola perusahaan. Tujuan pengawasan itu bukanlah mencari kesalahan akan tetapi mencegah dan memperbaiki kesalahan. Sering terjadi fungsi pengawasan itu disalah artikan yaitu mencari kesalahan orang lain atau sebagai alat menjatuhkan hukuman atas suatu kesalahan yang dibuat pada hal tujuan pengawasan itu untuk menjamin tercapainya tujuan-tujuan dan rencana perusahaan.

\section{Fungsi Koordinasi}

Fungsi koordinasi menuntut adanya keselarasan tindakan bekerja dari setiap individu atau bagian dalam perusahaan untuk mencapai tujuan. ${ }^{14}$ Dengan demikian untuk menciptakan adanya koordinasi diperlukan perencanaan yang baik, yang dapat menunjukkan keselarasan rencana antara satu bagian dengan bagian lainnya.

Anggaran yang berfungsi sebagai perencanaan harus dapat menyesuaikan rencana yang dibuat untuk berbagai bagian dalam perusahaan, sehingga rencana kegiatan yang satu akan selaras dengan lainnya. Untuk itu anggaran dapat dipakai sebagai alat koordinasi untuk seluruh bagian yang ada dalam perusahaan, karena semua kegiatan yang saling berkaitan antara satu bagian dengan bagian lainnya sudah diatur dengan baik.

\section{Anggaran Sebagai Pedoman Kerja}

Anggaran merupakan suatu rencana kerja yang disusun sistematis dan dinyatakan dalam unit moneter. Lazimnya penyusunan anggaran berdasarkan pengalaman masa lalu dan taksir-taksiran pada masa yang akan datang, maka hal tersebut dapat menjadi pedoman kerja bagi setiap bagian dalam perusahaan untuk menjalankan kegiatannya. ${ }^{15}$

Berdasarkan fungsi anggaran yang sangat penting dalam pencapaian tujuan perusahaan, maka anggaran harus disusun dengan mengacu pada prinsip anggaran

\footnotetext{
${ }^{13}$ Ibid.

${ }^{14} \mathrm{Ibid}$.

${ }^{15}$ Ibid.
} 
Rahmani Timorita Yulianti: Transparansi Anggaran : Suatu Upaya...

yaitu, transparan, akuntabel, disiplin anggaran (efisien, tepat guna, tepat waktu dan dapat dipertanggungjawabkan), keadilan (penggunaannya harus dialokasikan secara adil untuk kepentingan seluruh kelompok masyarakat), efisien dan efektif (harus dimanfaatkan sebaik-baiknya untuk meningkatkan pelayanan dan kesejahteraan bagi masyarakat). ${ }^{16}$

Di dunia usaha, sudah banyak yang menerapkan sistem anggaran berbasis kinerja, di mana semua manajer baik yang di tingkat pusat maupun kantor cabang dalam suatu organisasi berfungsi sebagai pusat pertanggungjawaban. Para manajer berperan sebagai basis perencanaan, pengendalian, dan penilaian kinerja unit yang dipimpinnya. Dengan adanya peran para manajer sebagai pusat pertanggungjawaban, dapat berfungsi untuk mendelegasikan tugas dan wewenang ke unit-unit yang memiliki kompetensi sehingga mengurangi beban tugas manajer pusat, di samping itu dapat pula mendorong kreativitas dan daya inovasi para bawahan.

Kalau dicermati, anggaran kinerja mengandung pesan yang sangat mendalam yaitu penyusunan anggaran yang menitikberatkan pada sistem pengendalian manajemen. Dengan demikian, keberhasilan suatu budget actions plan ${ }^{17}$ tidak hanya berhenti pada ketaatan realisasi terhadap rencana, tetapi yang lebih penting adalah hasil dan implikasi kinerja yang diharapkan dari pengeluaran anggaran tersebut.

\section{Integrasi Nilai-nilai Dasar Islam dalam Anggaran}

Ekonomi Islam dibangun berdasarkan nilai-nilai dasar Islam sebagai way of life. Islam adalah agama yang sempurna, yang mengatur seluruh sendi kehidupan manusia dan alam semesta. Kegiatan perekonomian manusia juga diatur dalam Islam dengan prinsip illabiyah. Sehingga, ekonomi dalam pandangan Islam adalah ekonomi yang berlandaskan ke-Tuhanan, yaitu bertitik tolak dari Tuhan dan memiliki tujuan akhir kepada Tuhan. ${ }^{18}$

Konsekuensi dari prinsip tersebut adalah, harta yang ada pada manusia, sesungguhnya bukan milik manusia, melainkan hanya titipan dari Allah swt agar dimanfaatkan sebaik-baiknya demi kepentingan umat manusia, yang pada akhirnya semua akan kembali kepada Allah swt untuk dipertanggungjawabkan, baik dari aspek produksi, distribusi dan konsumsi. ${ }^{19}$

${ }^{16}$ Nur Achmad Affandi, “Hak Rakyat Atas APBD”, Kedaulatan Rakyat, 18 Pebruari 2005.

${ }^{17}$ Admin,"Anggaran Kinerja”.

http://www.wawasandigital.com/index.php?option=com_content\&task=view\&id =7265\&Itemid=62. accessed pada tanggal 27 Agustus 2009 18:03:47 GMT.

${ }^{18}$ Taqiyuddin an-Nabhani, Membangun Sistem Ekonomi Alternatif; Perspektif Islam, (Surabaya: Risalah Gusti, 1996), hal. 50.

${ }^{19}$ Monzer Kahf, Ekonomi Islam: Telaah Analitik Terhadap Fungsi Sistem Ekonomi, alih bahasa machnun Husain, cet.1, (Yogyakarta: Pustaka Pelajar, 1995), hal.5. 
Adapun nilai-nilai dasar Islam yang terkait dengan perencanaan dan realisasi anggaran adalah kejujuran (sidq,amanah), keadilan, pertanggungjawaban, kemanfaatan dan kesejahteraan. Sedangkan integrasi nilai-nilai dasar Islam dalam anggaran,

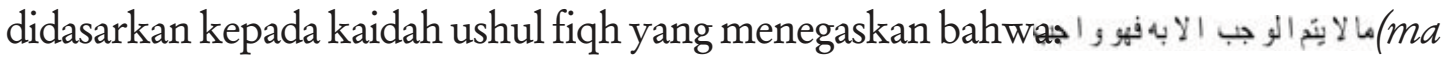
layatimmual-wajibu illa bibifabuwa wajib), yang artinya "sesuatu kewajiban tidak sempurna pelaksanaannya kecuali dengan adanya sesuatu hal, maka sesuatu bal tersebut bukumnya reajib pula". 20

Shidq (kejujuran) adalah suatu kewajiban. Dalam pengelolaan anggaran kejujuran tersebut tidak bisa dijalankan kecuali dengan penerapan prinsip transparansi anggaran. Berdasarkan kaidah tersebut maka, melakukan transparansi anggaran adalah wajib. Hal ini berarti, dalam pandangan Islam, menghindari transparansi anggaran adalah kemaksiatan.

Penerapan shidq ${ }^{21}$ sangat berkaitan dengan amana $b^{22}$. Bila amanab kuat, maka berkembanglah shidq. Dalam hal ini shidq berkaitan dengan proses informasi anggaran atau akuntabilitas anggaran (pertanggungjelasan anggaran), sedangkan amanab berkaitan dengan kesetiaan untuk mengalokasikan dan mendistribusikan anggaran kepada yang berhak dalam rangka implementasi nilai-nilai kemanfaatan, kesejahteraan dan pertanggungjawaban. ${ }^{23}$

Untuk mengontrol shidq dan amanah, diperlukan sistem pengawasan. Sistem kontrol atau pengawasan ini harus dilakukan dengan sangat tegas. Ia harus didukung oleh law enforcement yang mencerminkan nilai-nilai keadilan atau kesetaraan. ${ }^{24}$

Sehingga dengan mengacu kepada kaidah ushul fiqh di atas, dapat ditegaskan bahwa pengawasan anggaran adalah wajib karena, penerapan shidq dan amanah tidak akan berjalan, tanpa adanya pengawasan. Pengawasan tidak dapat dilakukan dengan baik tanpa transparansi anggaran. Oleh karena itu dalam perspektif ekonomi Islam, menegakkan transparansi ${ }^{25}$ anggaran adalah kewajiban agama Islam yang mulia.

Dengan demikian, penerapan transparansi anggaran akan menciptakan efisiensi terutama dalam pendanaan. Sebaliknya jika terdapat kecurangan, karena dipesan oleh pihak tertentu untuk menaikkan angka yang tidak sesuai dengan plafonnya, maka yang terjadi bukan hanya pembengkakan dana, tetapi sangat dimungkinkan terdapat penyalahgunaan atau korupsi.

${ }^{20}$ H.A.Djazuli, Kaidah-kaidah Fikih: Kaidah-kaidah Hukum Islam Dalam Menyelesaikan Masalah-masalah Yang Praktis, Edisi Pertama, Cetakan Ke-1, (Jakarta: Kencana Prenada Media Group, 2006), hal. 95-96.

${ }^{21}$ Lihat al-Qur'an surat Maryam ayat 41 dan 56, surat at-Taubah ayat 119.

${ }^{22}$ Lihat al-Qur'an surat al-Qashash ayat 26 dan surat An Nisa' ayat 58.

${ }^{23}$ Lihat al-Qur'an surat al-Baqarah ayat 282, surat al-Mujadalah ayat 7, surat al-Isra' ayat 34 dan 36, surat al-Furqan ayat 16, dan surat al-Ahzab ayat 15.

${ }^{24}$ Lihat al-Qur'an surat an-Nisa ayat 58 dan al-Hujurat ayat 13.

${ }^{25}$ Lihat al-Qur'an surat Ali Imran: 150 dan surat asy-Syura: 38 
Rahmani Timorita Yulianti: Transparansi Anggaran : Suatu Upaya...

Dalam kerangka inilah integrasi nilai-nilai dasar Islam dalam penyusunan anggaran menjadi persoalan yang fundamental dalam upaya efisiensi dan antisipasi korupsi. Dalam konteks ini integrasi nilai-nilai dasar Islam dalam bentuk peraturan pengawasan perusahaan, urgensinya sangat kuat, karena tidak semata-mata untuk kepentingan pribadi tetapi juga publik.

Karena korelasi ini pula, para pihak yang terlibat dalam penyusunan anggaran sudah seharusnya dikaitkan secara hukum, sehingga punya konsekuensi yang dapat dipertanggungjawabkan di muka pengadilan jika terjadi secara sengaja dalam pekerjaannya.

Penerapan nilai-nilai dasar Islam yang dikaitkan secara hukum tersebut, akan lebih jelas daripada hanya dikaitkan secara moral atau etis yang tingkat ketaatannya sangat bergantung pada kesadaran pribadi yang bersangkutan. Karena sifat ketaatan yang bersifat subyaktif tersebut menjadikan proporsi keterikatan relatif rendah.

Pemaksaan hukum dalam bentuk peraturan pengawasan perusahaan, memang masih terbuka lebar untuk didiskusikan. Tetapi dalam rangka antisipasi arus penyalahgunaan dana, urgensi dari pemberian sanksi hukum bagi para pihak yang terbukti bekerja tidak jujur, menjadi sangat kuat.

\section{Sistem Pengawasan Anggaran: Sebagai Upaya Efisiensi dan Antisipasi Korupsi}

Pengawasan atau pengendalian adalah suatu upaya sistematis untuk menetapkan standar prestasi kerja dengan tujuan perencanaan, untuk mendesain sistem umpan balik informasi, untuk membandingkan prestasi sesungguhnya dengan standar yang telah ditetapkan, menentukan adanya penyimpangan, dan mengambil tindakan perbaikan yang diperlukan, untuk menjamin bahwa semua sumberdaya organisasi telah digunakan dengan cara paling efektif dan efisien guna tercapainya tujuan organisasi. ${ }^{26}$

Pengawasan dalam pandangan Islam dilakukan untuk meluruskan yang tidak lurus, mengoreksi yang salah dan membenarkan yang hak. ${ }^{27}$ Dalam Islam, pengawasan terbagi menjadi dua:

\section{Pengawasan internal (built-in control)}

Pengawasan yang berasal dari diri sendiri ini bersumber dari tauhid dan keimanan kepada Allah swt. Falsafah dasar fungsi pengawasan dalam Islam muncul dari pemahaman tanggung jawab individu, amanah, dan keadilan. ${ }^{28}$ Pengawasan internal yang melekat dalam setiap pribadi muslim akan menjauhkannya dari bentuk

${ }^{26}$ Administrator, "Pengawasan Perspektif Islam" dikutip dari http://eei.fe.umy.ac.id/ index.php?option=page\&id=104\&item $=275$. accessed pada tanggal 6 Sep 2009.

${ }^{27}$ Abdul Mannan, Membangun Islam Kaffah, (Jakarta: Madina Pustaka, 2000), hal. 152.

${ }^{28} \mathrm{Ahmad}$ Ibrahim Abu Sinn, Manajemen Syariah: Sebuah Kajian Historis Dan Kontemporer, (Jakarta: PT. Raja Grafindo Persada), hal. 180. 
penyimpangan dalam pengelolaan anggaran dan menuntunnya konsisten menjalankan hukum-hukum Allah swt dalam setiap aktivitasnya.

Seseorang yang yakin bahwa Allah pasti mengawasi hambanya, maka ia akan bertindak hati-hati. ${ }^{29}$ Keyakinan tersebut akan menumbuhkan komitmen terkait dengan pengelolaan anggaran. Dengan demikian, perilaku inefisiensi dalam perencanaan anggaran dan perilaku korupsi dalam anggaran akan dihindari.

\section{Pengawasan Eksternal (external control)}

Pengawasan eksternal dilakukan dari luar diri manusia. Sistem pengawasan tersebut dapat terdiri atas mekanisme pengawasan dari pemimpin yang berkaitan dengan penyelesaian tugas yang telah didelegasikan, kesesuaian antara penyelesaian tugas dan perencanaan tugas terkait dengan anggaran dan lain-lain.

Adapun persyaratan pengawasan adalah sebagai berikut: ${ }^{30}$

\section{Pengawasan Membutuhkan Perencanaan.}

Sebelum teknik pengawasan dapat dipergunakan atau disusun sistemnya, pengawasan harus didasarkan kepada perencanaan yang jelas, lengkap, dan terpadu untuk meningkatkan efektivitas pengawasan.

\section{Pengawasan Membutuhkan Struktur Organisasi Yang Jelas}

Pengawasan bertujuan untuk mengukur aktivitas dan pelaksanaannya. Untuk itu harus diketahui orang yang bertanggung jawab atas terjadinya penyimpangan rencana dan yang harus mengambil tindakan untuk membetulkannya.

Adapun teknik pengawasan dalam Islam dirinci sebagai berikut: ${ }^{31}$

1. Teknik Pengawasan Tradisional dalam Bentuk Anggaran.

Penganggaran adalah perumusan rencana dalam angka-angka untuk periode tertentu di masa depan. Dengan demikian, anggaran adalah laporan tentang hasil-hasil yang diantisipasikan dalam angka keuangan _seperti dalam anggaran penghasilan dan pengeluaran serta anggaran modal_atau dalam istilah yang non keuangan seperti dalam anggaran jam tenaga kerja langsung, bahan baku, volume penjualan fisik atau produksi unit.

2. Teknik Pengawasan Tradisional Non Anggaran.

Dalam teknik ini terdapat banyak sarana pengawasan tradisional yang tidak ada hubungannya dengan anggaran, meskipun beberapa di antaranya sedikit banyak ada hubungannya dengan pengawasan

${ }^{29}$ Lihat al-Qur'an surat al-Mujadalah: 7, al-Maảidah: 8, al-Hujurat: 6, Qaaf:16-18, al-An'aam: 59.

${ }^{30}$ Administrator, "Pengawasan Perspektif Islam" dikutip dari http://eei.fe.umy.ac.id/ index.php?option $=$ page\&id=104\&item $=275$. accessed pada tanggal 6 Sep 2009.

${ }^{31}$ Ibid. 
Rahmani Timorita Yulianti: Transparansi Anggaran : Suatu Upaya...

anggaran. Sarana yang paling penting di antaranya adalah data statistik, laporan dan analisis khusus, audit operasional, observasi personal, dan analisis jaringan waktu kejadian.

Sedangkan fungsi manajerial pengawasan adalah untuk mengukur dan mengoreksi prestasi kerja bawahan guna memastikan bahwa tujuan organisasi di semua tingkat dan rencana yang didesain untuk mencapainya, sedang dilaksanakan. Pengawasan membutuhkan prasyarat adanya perencanaan yang jelas dan matang serta struktur organisasi yang tepat.

Dalam konteks ini, integrasi nilai-nilai dasar Islam dalam perencanaan anggaran diwujudkan melalui tiga pilar pengawasan, yaitu : ${ }^{32}$

\section{Ketaqwaan individu.}

Seluruh personel sumber daya manusia dipastikan dan dibina agar menjadi SDM yang bertaqwa. Dengan implementasi taqwa di setiap tempat dan waktu, maka taqwa tersebut mampu menjadi kontrol yang paling efektif

\section{Kontrol anggota.}

Dengan suasana organisasi yang mencerminkan formula tim, maka proses keberlangsungan organisasi selalu akan mendapatkan pengawalan dari para SDM-nya agar sesuai dengan arah yang telah ditetapkan. Dalam hal ini perlu disusun mekanisme saling mengawasi antar sesama secara horizontal.

\section{Supremasi Hukum.}

Organisasi ditegakkan dengan aturan main yang jelas dan transparan. Sistem pengawasan yang baik tidak dapat dilepaskan dari pemberian punishment (hukuman) dan reward (imbalan). Bentuk reward tidak harus materi tetapi dapat berupa penghargaan atau promosi jabatan. ${ }^{33}$

Berdasarkan kepada paparan tentang pengawasan di atas, integrasi nilai-nilai dasar Islam dalam sistem pengawasan anggaran dari perencanaan sampai kepada realisasinya menjadi suatu yang penting dalam upaya inefisiensi dan pemberantasan korupsi.

Sistem pengawasan anggaran tersebut bukan hanya ajakan moral semata, tetapi dalam bentuk peraturan pengawasan anggaran dalam setiap perusahaan atau organisasi baik mekanisme formal maupun mekanisme masyarakat, sehingga terdapat mekanisme reward (penghargaan) bagi yang berprestasi dan punishment (sanksi) bagi yang melakukan penyimpangan.

${ }^{32}$ Ibid.

${ }^{33}$ Didin Hafidhuddin dan Hendri Tanjung (2003), Manajemen Syariab dalam Praktik (Jakarta: Gema Insani Pers), p.158 
Rahmani Timorita Yulianti: Transparansi Anggaran: Suatu Upaya...

\section{Penutup}

Sebagai suatu upaya efisiensi dan langkah antisipasi korupsi di Indonesia, adanya sistem pengawasan anggaran baik mekanisme formal maupun masyarakat, sudah selayaknya diadakan, meskipun upaya tersebut relatif masih dipertanyakan hasilnya. Karena yang akan berjuang untuk menentangnya adalah para pihak dari banyak kalangan yang sudah terbiasa dengan perilaku korupsi. Mereka mempunyai kepentingan besar untuk berkolusi dengan fenomena penyusunan anggaran yang tidak islami.

Selain itu dengan langkah yang cukup canggih, mereka tidak akan bosan melakukan sejumlah manuver guna mempertahankan praktik penyusunan anggaran yang jauh dari nilai-nilai Islam. Realitas tersebut menjadi suatu tantangan bagi semua pihak yang terkait dengan implementasi nilai-nilai dasar Islam di Indonesia; apakah akan tergerak untuk merealisasikan peraturan pengawasan anggaran dengan sejumlah konsekuensinya, atau memilih "tutup mata" dengan konsekuensi pahit yang akan diterimanya, yaitu pembiaran perilaku menyimpang dalam mengelola anggaran.

\section{DAFTAR PUSTAKA}

Dahlan, Abdul Azis et. al. (1996), Ensiklopedi Hukum Islam, cet.1, Jakarta: Ichtiar Baru Van Hoeve.

Mughits, Abdul (2008), “Kompilasi Hukum Ekonomi Syari”ah(KHES)Dalam Tinjauan Hukum Islam”, Al Mawarid Jurnal Hukum Islam, Edisi XVIII Tahun 2008, pp. 141-159.

asy-Syairazi, Abu Ishaq (t.t.), al-Luma'fi Usul al-Fiqh, cet. 1, Surabaya: Ahmad Bin Nabhan.

Admin (t.t.) "Anggaran Kinerja" dikutip dari http://www.wawasandigital.com/ index.php?option $=$ com content\&task $=$ vi $\quad$ ew\&id $=7265 \&$ Itemid=62, diakses 27 Agustus 2009.

Admin (t.t.), "Modus Korupsi", dikutip dari http://www.transparansi.or.id/ ?pilih=lihataboutcorruption\&id=7, diakses 27 Agustus 2009.

Welsch, Glenn A. (1981), Budgeting Profit Planning and Control, Fourth Edition, New Delhi: Prentice Hall of India Private Limited.

Djazuli, H.A. (2006), Kaidab-kaidah Fikib: Kaidab-kaidab Hukum Islam dalam Menyelesaikan Masalah-masalabyang Praktis, Edisi Pertama, Cetakan Ke-1, Jakarta: Kencana Prenada Media Group.

Hafidhuddin, Didin dan Tanjung, Hendri (2003), Manajemen Syariah dalam Praktik, Jakarta: Gema Insani Pers.

Motzki, Harald (2000), The Origin of Islamic Jurisprudence:Meccan Figh before the Classical Schools, Leiden: Brill.

Ibn Manzur (t.t.), Lisan al-'Arab, II. 
Rahmani Timorita Yulianti: Transparansi Anggaran : Suatu Upaya...

Indonesia Corruption Watch (2006), “Korupsi Anggaran”, Materi Training Yogyakarta 29 Agustus - 1 September 2006.

Purbadharmaja, Ida Bagus Putu (2007), "Kajian Terhadap Fungsi Anggaran Dalam Pembangunan Ekonomi Daerah”, Buletin Studi Ekonomi, Vol. 12, No. 3.,pp. 271-8.

Siregar, Iskandar (2009), "Menuju Era Transparansi Anggaran”, dikutip dari http:// www.kabarindonesia.com/berita.php?pil =20\&jd = Menuju + Era+Transparansi + Anggaran \&dn=20080627090126, diakses 11 Agustus 2009.

Sonhadji, Iskandar (2008), "Perilaku Korupsi Dan Dampaknya", dikutip dari http:// www.nu-antikorupsi.or.id/page.php?display $=$ dinamis\&kategori $=3 \& \mathrm{i}$ $\mathrm{d}=198$, diakses 22 Juli 2008 .

Kompas, 25 Mei 2003.

Ma'luf, Louis (1973), al-Munjid fial-Lughab wa al-Adab wa al- Ulum, cet. 22 .Beirut:Dar al-Masyriq.

Masodah (t.t.), "Penganggaran Perusabaan (Budgeting)", dikutip dari http:// www.google.co.id/search?hl=id\&cr= countryID\&q = related:maso dah.staff.gunadarma.ac.id/Downloads/files/6633/Pp3.doc.

Kahf, Monzer (1995), Ekonomi Islam: Telaah Analitik Terhadap Fungsi Sistem Ekonomi, terj. Machnun Husain, cet. 1, Yogyakarta: Pustaka Pelajar.

Affandi, Nur Achmad (2005), "Hak Rakyat Atas APBD”, Kedaulatan Rakyat, 18 Februari 2005.

Marzuki, Peter Mahmud (2006), Penelitian Hukum, Jakarta: Kencana.

Yulianti, Rahmani Timorita (2008), "Korupsi:Problematika Dan Upaya Pemberantasannya” Al-Mawarid Jurnal Hukum Islam, Edisi XIX Tahun 2008, pp. 21-36.

Syahatah, H.H. (2005), Suap dan Korupsi dalam Perspektif Syariah, terj. K.A. Irsyadi, Jakarta: Amzah.

Anwar, Syamsul (2007), Hukum Perjanjzan Syariah, Jakarta: PT. Raja Grafindo Persada. an-Nabhani, Taqiyuddin (2006), Membangun Sistem Ekonomi Alternatif:Perspektif Islam, Surabaya: Risalah Gusti.

Winardi (1983), Azas-azas Manajemen, Edisi Ketujuh, Bandung: Penerbit Alumni. 